\title{
Open Innovation dan Risk Governance dalam Entrepreneurial Behavior
}

\author{
Cahyo Adityo Irawan
}

S130118033@ubaya.student.ac.id

Entrepreneurial Orientation (EO) merupakan pengenalan strategi kewirausahaan untuk mendukung perubahan dan mendukung kegiatan yang berkaitan dengan pemanfaatan berbagai bentuk inovasi, pengembangan produk / layanan baru dan penciptaan nilai pelayanan yang unggul. EO memainkan peran penting dalam mengembangkan, mengkomersialkan, dan mengembangkan produk dan layanan baru serta mengantisipasi dan menanggapi kemungkinan yang terjadi dalam perusahaan. Perusahaan dengan EO yang kuat berfokus pada pencapaian kinerja yang unggul dengan membangun strategi penciptaan nilai yang tidak dapat ditiru oleh pesaing lain atau sulit untuk ditiru. Oleh karena itu, kewirausahaan dengan orientasi strategis mengabaikan keuntungan dalam jangka pendek dan berinvestasi dalam peluang risiko yang lebih tinggi untuk manfaat jangka panjang dan penciptaan nilai. Hasilnya, perusahaan dapat menghasilkan produk atau layanan baru dan inovatif, secara kreatif mengungguli pesaing. (Tajeddini, Martin, \& Ali, 2020)

Inovasi terbuka adalah proses yang memungkinkan pengetahuan dan sumber daya inovasi mengalir secara bebas dan telah menjadi pendekatan yang dominan untuk merevitalisasi suatu suatu proses inovasi perusahaan. Para akademisi telah mengakui pentingnya strategi inovasi terbuka, sebagaimana dibuktikan oleh sejumlah besar penelitian yang ditujukan. Inovasi terbuka terdiri dari dua bentuk, yaitu inbound (fokus pada akuisisi teknologi eksternal) dan outbound (eksploitasi teknologi eksternal) dan dua bentuk inovasi terbuka ini untuk menciptakan konstruksi tunggal. (Liao, Fu, \& Zhiying, 2020)

Mengambil dan mengelola resiko melibatkan kemauan untuk mengambil tindakan tegas seperti memperkenalkan produk baru atau memasuki pasar baru, melakukan sumber daya dalam kondisi yang tidak pasti dan meminjam. Meskipun pengambilan risiko bisa di tingkat individu, ini adalah sifat tingkat perusahaan dalam konteks EO menggambarkan risiko kewirausahaan yang melibatkan ketidakpastian dan potensi kerugian finansial. Elemen kunci kewirausahaan di tingkat perusahaan termasuk inovasi dan pengelolaan risiko (Seet, Lindsay, \& Kloop, 2020)

Open Innovation melibatkan struktur jaringan, kepercayaan, pengembangan produk, dan bagaimana kinerja oleh perusahaan. Baik kepercayaan atau pengembangan produk memainkan peran penting pada usaha kecil menengah yang diamati dengan memberikan efek mediasi pada dua hubungan antara struktur jaringan dan kinerja perusahaan. Informasi yang digunakan untuk menjawab pertanyaan penelitian mengacu pada hubungan antara variabel yang diamati yaitu dengan variabel independen, mediasi, dan moderasi termasuk kinerja perusahaan, struktur jaringan pada sosial, kepercayaan, dan pengembangan produk. (Pratono, Network structure and open innovation: the role of trust in product development, 2018) 
Perilaku pengambilan risiko menghasilkan berbagai macam hasil. Butuh penyelidikan lebih lanjut untuk pemahaman yang lebih baik tentang bagaimana kondisi keterlibaan perusahaan dalam meningkatkan atau mengurangi risiko. Perilaku pengambilan risiko muncul saat perusahaan mengambil keputusan untuk menetapkan harga. Penelitian menggunakan model persamaan struktural untuk menentukan hubungan antara perilaku pengambilan risiko, yang muncul dari literatur pengukuran dan fundamental yaitu metode statistik multivariat untuk mengetahui hubungan variabel laten. Ada empat variabel laten yang terdiri dari perilaku pengambilan risiko, kinerja perusahaan, kapabilitas harga dan turbulensi teknologi informasi. (Pratono, Does firm performance increase with risk-tasking behavior under infornation technological turbulence?, 2018)

\section{References}

Liao, S., Fu, L., \& Zhiying, L. (2020). Investigating open innovation strategies and firm performance: the moderating role of technological capaility and market information management capability. Journal of Business \& Industrial Marketing, 35(1), 23-29.

Pratono, A. H. (2018). Does firm performance increase with risk-tasking behavior under infornation technological turbulence? The Journal of Risk Finance, 19(4), 361-378. doi:10.1108/JRF-10-20170170

Pratono, A. H. (2018). Network structure and open innovation: the role of trust in product development. Int. J. Business Innovation and Research, 15(1), 44-61.

Seet, P.-S., Lindsay, N., \& Kloop, F. (2020). Understanding early-stage firm perforance: the explanatory role of indovideual and firm level factors. International Journal of Manpower.

Tajeddini, K., Martin, E., \& Ali, A. (2020). Enhancing hospitality business performance: The role of entrepreneurial orientation and networking ties in a dynamic environment. International Journal of Hospitality Management, 90. doi:10.1016/j.ijhm.2020.102605 